\title{
Financing of Technical and Vocational Education and Training in Nepal
}

\author{
Baikuntha Prasad Aryal* \\ Kathmandu University School of Education, Lalitpur, Nepal
}

\begin{abstract}
Considering Technical and Vocational Education and Training (TVET) sector as an enabler for the socio-economic transformation of the nation, preparing competitive, skilled human resources has become a global priority, which has ushered increased financing in TVET. Of late, TVET governance has become a greater policy concern in Nepal mainly to address the constitutionally designated functions between the three tiers of government as well as to establish a sustainable financing mechanism for better TVET service delivery. Mixed methods approach was applied using survey, questionnaire and focused group discussion, including secondary information to capture the current TVET financing domain from the federal line ministries. The study found that TVET financing has been influenced mainly by the national economy, equity and inclusion, inter-governmental coordination, global political context, external funding, private sector engagement, and mobilisation of the youth. This study reveals that though the trend of budget allocation for TVET is highly correlated to the total national budget and total education budget, the actual allocation still seems significantly low to achieve the Sustainable Development Goal 4 targets and the government policy of quality expansion of TVET. The study explores specific models on TVET financing and indicates the viability of integrating funds so that TEVT can serve as an avenue for national prosperity.
\end{abstract}

Keywords: TVET, financing pattern, fiscal equalisation, political economy, sustainability

* Author Email: baikunthaparyal@gmail.com https://orcid.org/0000-0001-9005-1087

Journal homepages:
ISSN: 2091-0118 (Print) / 2091-2560 (Online)

(C) 2020 The Author(s).

${ }^{1}$ http://www.kusoed.edu.np/journal/index.php/je

${ }^{2}$ https://www.nepjol.info/index.php/JER/index

Published by Kathmandu University School of Education, Lalitpur, Nepal.

This open access article is distributed under a Creative Commons Attribution (CC BY-SA 4.0) license. 
Financing of TVET in Nepal | 59

\section{Introduction}

Financing of technical and vocational education and training (TVET) to a great extent has been a long-standing issue across the globe (e.g. International Centre for Technical and Vocational Education and Training of the United Nations Educational, Scientific and Cultural Organization [UNESCO-UNEVOC], 1996). Consequently, this issue has generated dozens of studies on TVET, which, in turn, have answered questions associated with the mechanism of TVET financing in many ways. Some of the innovative mechanisms that have been adopted for TVET financing in several national training systems consist of cost-sharing, development partners' support, income from services and productions, co-financing with private sectors, levy-grant scheme, fees for services, among others which address the shortcomings of the conventional finance systems to improve both the quality and relevance of TVET (Karmel, 2015; Ziderman, 2016). Furthermore, financing TVET is considered a crucial issue since it demands a considerably high cost, basically because of expenditures on equipment, infrastructure, instructors, including several other consumables, raw materials and spare parts (UNESCO-UNEVOC, 1996). This could be one of the reasons why countries like Nepal have been advised to consider output-based funding approach on TVET (Renold \& Caves, 2017).

In the past, varieties of TVET financing mechanisms have been adopted in different parts of the world. UNESCO-UNEVOC (1996) has clustered them into four types of practices: (a) Public Financing, (b) Enterprise Financing, (c) Private and Public Sponsored Financing and (d) International Donor Assistance. But the current global movement is increasingly moving towards a cost-sharing mechanism between the public and other sectors in order to ensure the quality and relevance of TVET programmes (UNESCO-UNEVOC, 1996).

Literature shows that there is a strong association between education and employability (e.g. International Commission on Financing Global Education Opportunity, 2016; Vollmann, 2010). Labour Force Survey 2017/18 claims that individuals who have a high level of education and skills would have better labour market outcomes (Central Bureau of Statistics, 2019). A similar outcome was also observed in China, which asserts that the development of high-quality skills and experience has a good promoting effect on the formation of graduate employability 
$60 \mid$ B. P. Aryal

(Chen, 2017). Keeping this in view and to utilise education for skill development and increase production, employability and prosperity, the Government of Nepal has taken TVET as a means for achieving its long-term vision of "Prosperous Nepal, Happy Nepali” by 2043 (National Planning Commission [NPC], 2019).

The Government of Nepal has recently formulated a national education policy including TVET policy with the clear objective to expand the opportunities of TVET to prepare capable, efficient, and competitive human resources for the economic development of the country (Ministry of Education, Science and Technology [MOEST], 2019). The government has also put a policy in place to ensure access to quality TVET through inclusion, promotion and development of the indigenous skills (Ministry of Education [MOE], 2012). The 2015 constitution of Nepal entails having a strong partnership with private and cooperative sectors to ensure sustained economic growth for the nation (Ministry of Law, Justice and Parliamentary Affairs, 2015). However, the functional clarity and a robust mechanism of financing TVET are yet to be decided in line with the constitutional mandates between and among the three levels of governments of Nepal. So, the new federal system of the country has extensively called for reengineering and streamlining of TVET governance and financing mechanism.

\section{Justification}

The Asian Development Bank ([ADB], 2009) has explored the debate on TVET financing as it is considered to be a "public good" and can be treated as a part of the market. The debate has also been explored by UNESCO (2003) and followed by Fuller and Unwin's (2013) through some basic questions such as (a) what should be the roles of the state in the financing of TVET? and (b) Does the expansion of private institutions on TVET firmly signify a better sign of mobilising local resources or has it unknowingly created disparities in the contemporary societies?

It has become an unfinished agenda of finding sustainable sources for TVET across the globe in general and particularly in developing countries like Nepal. In Pakistan, India and Thailand, TVET is mainly financed through public funds followed by a small share of industries and vocational training institutes (UNESCO-UNEVOC, 1996), but in the case of Nepal, government finance has remained exclusively the foremost contributor compared to employers and trainees (Center for Research and Development 
Financing of TVET in Nepal $\mid 61$

Services [CRDS], 2018). This is in stark contrast to the idea of public-private partnership in TVET, one of the development agendas of the government of Nepal adopted not only to decrease large-scale foreign migration of the country's youth population but also to promote locally sustained entrepreneurship (NPC, 2019). In addition, the government of Nepal has been seeking private sector's engagement as well as development partners' investment to expand TVET services in all 753 local levels across the country.

However, ensuring financial sustainability in TVET has become very difficult due to competing demands of other development sectors of Nepal. For instance, of the total education budget, basic education consumes the highest share, followed by secondary education and higher education. As a result, the share of the budget earmarked for the development of TVET sub-sector varies from year to year, constantly remaining below $7 \%$ of the total education budget of Nepal (Ministry of Finance [MoF], 2017, 2018 \& 2019). However, studies (for example, CRDS, 2018) reveal that the share of TVET budget in most countries across the world remains between $1-12 \%$ of the total education budget. Such evidence discloses a visible gap between the Nepal government's policy to provide skills to all the youths and its financing strategy to meet the national plan and SDG targets. Recognising the need for more sustainable financing in TVET, the Government of Nepal has been trying to identify and initiate new sources of funding for TVET and create a strong link between the three levels of government in Nepal for such financing mechanism and enhance private sector engagement for the same. Available information on the current financing patterns and the future course of TVET financing in the changing political and economic context of Nepal is mainly sketchy and inadequate. Hence this study intends to make an in-depth investigation of these issues.

\section{Objectives of the Study}

This research paper aims to answer the following questions:

a) What are the current financing patterns of Technical \& Vocational Education and Training (TVET) financing in Nepal?

This question firmly examines the current investment patterns of both the public and private sectors in TVET. Simultaneously, it identifies the financial gaps and practical 
$62 \mid$ B. P. Aryal

propositions to attain the reform agenda of the Government of Nepal in the TVET sector.

b) What are the pertinent solutions of funding and alternatives to increase financing for TVET in the federal system of Nepal?

The second question explicitly complements the first question. Since the current trends of financing on TVET does not accommodate the changing requirements of the nation, this question, therefore, analyses the existing intergovernmental fiscal transfer policy and its strategy and implications to the extent of strengthening quality Technical and Vocational Education and Training in Nepal. In addition, it also classifies both the TVET and Non-TVET activities, including major challenges of as well as alternative options to integrate TVET financing in the federal governance system of Nepal.

\section{Process of the Study}

In order to answers these questions, both quantitative and qualitative methods have been blended in this study so as to ensure the validity and reliability of the information provided (Best \& Kahn, 2002). The study has followed the survey technique recommended by Dubin (1978) with the aim of providing hints both for theory building and for theory refinement in case of Nepal's future TVET financing. The study, therefore, used various tools such as interviews, questionnaires, retrospective reports, and electronic communication to identify fund flow mechanisms and governance systems of TVET across the federal line ministries.

The secondary information was the major source of this study. However, key questionnaires were developed to estimate the current TVET financing domain of the federal line ministries, which were then used as the primary source. The secondary data derived from several relevant organisations were carefully analysed to explore the possible options to make future TVET more responsive and effective to both national demands and global changes.

\section{Conceptual Framework of TVET Financing}

Expansion of quality TVET requires huge financial resources which is only possible through strengthening and institutionalising the national economy. Institutionalising economy has been regarded as political and economic motives, whereas reducing disparities has been viewed as social explanations (Wang, 1977). Financing in

Journal of Education and Research, Vol. 10, No. 1, 2020 
Financing of TVET in Nepal $\mid 63$

education in general and TVET, in particular, is guided by the political economy. In contrast, the superstructure (politics) always serves its substructure (economics) to meet the basic requirements (Eatwell et al., 1987, as cited in Mosco, 2009). The principle of the political economy contributes not only to the existing political context but also affects the entire substructures, including education of the country. It creates new echelons to the local political and economic activities in terms of designing capital, labour and financing laws (Kennedy, 2013). In the case of Nepal, the existing federal set up of the country and the governance restructuring process with new funding modality demands a new developmental framework in all sectors of development, including TVET sector.

Thompson (2000) suggests that the evolutionary paradigms of the global political economy have become a contributory factor in shaping both regional and national politics. However, such consequences have heavily facilitated to bring innovations in technical and economic dimensions. Thompson (2000) further claims that the political economy in this regard has appeared as a strong determinant for formulating and implementing public policy reform in the contemporary world (ADB, 2009; Grindle \& Thomas, 1991).

Development partners and multinational organisations are the main forces that influence decision-making in the educational sector in many developing countries, regardless of actual need (Kingdon et al., 2014). Nepal is now utilising the support of its development partners to strengthen the TVET system of the country. But such kinds of support are being provided in different ways and patterns and according to the liking of the development partners. This is also a form of political economy which is concerned with the distribution of power and wealth between interest groups (Hatlebakk, 2017). And this could be one of the reasons that contemporary scholars widely accepted a notion that even single support given by the development partners is steeped in the vested interest. Hatlebakk further claims that political economy either blocks or accelerates the educational reform agenda. Thus, the insights gained from the literature help us conclude that the role of political economy firmly examines the politics and its contribution to the development consequences, including education outcomes. 
64 | B. P. Aryal

\section{Global Practices of TVET Financing}

The practice of financing TVET has been rather varied across different countries. For instance, Cambodia introduced a per-capita funding modality in TVET, but the calculation of the unit cost remained a problematic issue since the unit cost varied from one occupation to another (UNESCO, 2013). This could be the reason why many countries in the world later moved towards a sectoral (industry-specific) training fund model as an alternative despite its failure in reducing the duplications and developing common core skills required in the market (Johansen, 2009). To address this issue, Johansen (2009), therefore, discovered three major categories of TVET fund after reviewing more than 60 countries' cases: (i) pre-employment training fund; (ii) equity training fund; and (iii) enterprise training fund. According to the author, the preemployment training fund is for providing opportunity and balancing the market demand and supply, while the enterprise training fund is for in-service training to increase productivity and competitiveness. The equity training fund, on the other hand, is for increasing access to the targeted groups. However, the sources of these models are varied.

The German system, popularly known as the dual apprenticeship system, and Japanese enterprise system enormously focus on the enterprise-based training system and take responsibility for the financing of training programmes to ensure the needed skills of the market (Alam, 2015). The company or industry-based TVET delivery system has persisted in Vietnam as well regardless of the lack of attractive incentive packages to the private sectors since institutions enjoy the liberty to determine the fee levels and government's fund flows through per-capita funding modality (General Directorate for Vocational Training, 2007).

Interestingly, the case of the South Asian countries appears to be different. Despite a well-established technical and vocational education and training (TVET) system in Sri Lanka, finding sources of sustainable financing in TVET has been a major issue in the public sector due to a high financial and economic costs of pre-employment training programmes run by public sectors (ADB, 2015). This has led to the practice of establishing skill development fund has been gaining momentum in many developing countries. For example, the government of Pakistan envisions that TVET financing is a cost-sharing responsibility between governments, employers and learners/trainees, in 
Financing of TVET in Nepal $\mid 65$

which cost-sharing entitles as fees to be paid by learners/trainees, loan or bursary, levy and grants (Ministry of Federal Education and Professional Training/Pakistan, 2015). The government of Nepal has made an explicit policy provision of establishing a TVET fund to mobilise the resources through a joint investment of the government of Nepal, private sectors and development partners in order to increase access and improve quality in TVET (MOE, 2012).

Similarly, the National Skills Development Policy, 2011 of Bangladesh envisions establishing a national human resource development fund to ensure equity and better service of TVET through labour market responsive delivery mechanism (Ministry of Education/Bangladesh, 2011). The policy has fixed a target of allocating $1 \%$ contribution to the fund out of the total remittance received by Bangladesh in a year. The policy further envisages that micro-credit mechanism has been taken as a tool to provide support for both trainees and training providers through the operationalisation of the fund. One of the prime sources of financing is a compulsory revenue-generating payroll levy in Brazil by operationalising the pre-employment fund to balance the current supply and demand of labour forces (Johansen, 2009). In Nepal, financing of TVET has been mainly ensured by government funds followed by private-sector sources with the aim of ensuring equity in TVET (Parajuli, 2013). The informal sector's contributions -such as individual, household, and community sources - have been a major source of TVET funding in Nepal, the author highlights. It is apparent that the government of Nepal basically finances the public sectors and trainees are subject to pay fees in privately run technical training providers (TTPs) in Nepal citing the example of CTEVT, which runs its major TVET activities through government grants and allows TTPs to also charge fees (ADB, 2015).

TVET programmes and activities have been addressing and implementing crosscutting themes throughout different sectors of Nepal such as education, health, labour, tourism, agriculture and cooperatives, industry, among others. Therefore, the MoEST, including other federal ministries and CTEVT, are heavily engaged in the implementation of various kinds of TVET activities. And although all these efforts have still not been able to attract enough students in skill development and production, TVET is still taken as a viable alternative to the general education system (Vollmann, 2010). Thus, exploring financing of TVET in Nepal requires the review of the mandates 
$66 \mid$ B. P. Aryal

of these agencies, which is complex because of the varied nature of these scattered agencies and mechanisms (Parajuli \& Shakya, 2012).

The literature helps draw a conclusion that the TVET stakeholders have varied interest. For example, employers always attempt to recruit qualified workers from the market. The government is interested in maintaining sustainable financing since TVET consumes a significant amount of resources. Therefore, those who can pay for training courses are the target groups of the technical training providers and the job seekers, in turn, want a decent and better paying job. Thus, following the suggestions of Renold et al. (2018), in the federal context of Nepal, it needs to be explored whether establishing a pooling mechanism and allocating budget through per-capita funding modality would be instrumental for translating these varied interests into a common framework of financing of TVET in Nepal.

Evidence from the literature demonstrates that there are four different dimensions of financing TVET (ADB, 2009): (a) what are the purpose and aims of TVET, (b) how to ensure value for money, (c) who should pay for TVET and (d) what would be a suitable mechanism to transfer the funds from the source to the destinations. The cumulative purpose of these dimensions is to investigate a best-managed mechanism of financial flow on TVET. These are equally crucial issues in the changed federal governance system of Nepal. The provisions of constitutional concurrent authorities, including TVET, have further required to establish a strong inter-coordination mechanism among three levels of government (MOEST, 2019).

Vollman (2010) further says that the lack of political support for TVET, sociocultural values, limited TVET opportunities in rural areas, including traditional marriage patterns, community tradition that governs specific jobs and skills which are to be exercised by a special group of people, the generational transmission of traditional professional skills (belonging to well-defined sub-caste), as well as the religious, linguistic and ethnic values and beliefs are the major challenges to strengthen TVET in South Asia, and particularly in the case of Nepal. Similarly, the questions as to how to increase public support for the development of TVET sector while ensuring commitment from all levels of the government, and, concurrently, develop integrated national TVET system as well as a required human resource in the field of TVET by increasing the systemic capacity and maintain the linkage of TVET in relation to the 
Financing of TVET in Nepal $\mid 67$

labour market are some of the additional challenges in TVET sector of Nepal (Parajuli \& Shakya, 2012).

To address the aforementioned challenges, the government of Nepal has adopted the fiscal equaliser policy to ensure equitable resource allocation at all levels of the governments where most of the budgetary responsibilities are assigned to sub-national governments (Dung, 2015). In line with the fiscal equaliser policy, it is assumed that economic efficiency and prosperity can be enhanced through the horizontal competition between sub-national governments guided by the Second-Generation Theory (Ejoboha, 2018).

\section{Overview of TVET Financing in Nepal}

Due to the changed political context of the country, the new government with leftwing ideology has given utmost priority to equity and inclusion in education, including TVET. As per the observations made by Braga et al. (2013), the left-wing ideologies basically favour inclusive education reforms, whereas right-wing ideologies focus on selective education reforms without examining the financing determinant as a vital contributor. While analysing the manifestos of the current political parties related to left-wing ideologies of Nepal, prime importance has been given to the TVET sector. As a result, the current Government of Nepal has announced that the public expenditure will be primarily focusing on TVET and the government will establish at least one TVET institution in each of all local levels across the country. In light of this, how does the political economy shape the financing of education has become a crucial question in public education reform in the federal context of Nepal.

\section{Trend of Financing TVET in Nepal}

The human capital theory claims that investment in education and training is not the cost rather an investment for future benefits (Becker, 1994). Education has been considered as a vehicle to contribute towards skilled human capital (Hasan \& Mokhtar, 2013). This could be the reason why many countries in the world have started prioritising financing in TVET so as to develop specific human capital. TVET sector demands higher cost compared to the general education, so the governments seek various sources to meet the required investment in TVET. For instance, particularly in the developed countries, a chunk of investment in TVET has been mobilised from private sectors (business and industries), including student fees, employee levy and so 
on and so forth. But in contrast, developing countries have been facing acute shortage of budget in TVET and mostly relying on the government budget and support from development partners to some extent (ADB, 2014).

Taking into account both public and private sources of financing TVET, OECD countries have been spending almost $6.0 \%$ of their GDP on education, including TVET. The highest share of this investment is found in Denmark, Iceland, Korea and the United States, with at least 7.0\% of GDP, followed by Mexico and New Zealand with more than $6.5 \%$ (ADB, 2009). The author further identifies that the proportion of Greece and the Russian Federation is $4.2 \%$ and $3.8 \%$ respectively. However, the corresponding figures sharply declined in the case of developing and least developed countries. For example, Nepal spends almost 3.4\% of GDP in education (Ministry of Finance, 2019) whereas Bangladesh spends 2.5\%, India 3.8\%, Mongolia 3.5\%, Sri Lanka 3.2\% and Pakistan spends about 2.3\% of its GDP to education (ADB, 2009, 2014). At the same time, Bhutan and Maldives spend $5.9 \%$ and $7.0 \%$ in education to their GDPs respectively.

In this regard, the allocation of the government budget for the entire education sector of Nepal seems more or less comparable. Still, the budget allocated in TVET has not been evenly distributed (see Table 1).

Table 1

Comparative Analysis of TVET Budget in Nepal

\begin{tabular}{|c|c|c|c|c|c|c|c|c|c|c|}
\hline $\begin{array}{l}\text { Fiscal } \\
\text { Year }\end{array}$ & $\begin{array}{l}\text { Total } \\
\text { national } \\
\text { Budget } \\
\text { (NPR in } \\
\text { Million) }\end{array}$ & $\begin{array}{l}\text { Total } \\
\text { education } \\
\text { budget } \\
\text { (NPR in } \\
\text { Million) }\end{array}$ & $\begin{array}{l}\text { TVET } \\
\text { Budget } \\
\text { of } \\
\text { MoEST } \\
\text { (NPR in } \\
\text { Million) }\end{array}$ & $\begin{array}{l}\text { TVET } \\
\text { Budget of } \\
\text { other Line } \\
\text { Ministries } \\
\text { (NPR in } \\
\text { Million) }\end{array}$ & $\begin{array}{l}\text { TVET } \\
\text { Budget } \\
\text { from } \\
\text { DPS } \\
\text { (NPR } \\
\text { in } \\
\text { Million) }\end{array}$ & $\begin{array}{l}\text { Annual } \\
\% \\
\text { change } \\
\text { in } \\
\text { total } \\
\text { nation } \\
\text { al } \\
\text { budget }\end{array}$ & $\begin{array}{l}\text { Annual } \\
\% \\
\text { change } \\
\text { in } \\
\text { total } \\
\text { educat } \\
\text { ion } \\
\text { budget }\end{array}$ & $\begin{array}{l}\text { Annual } \\
\% \\
\text { change } \\
\text { in } \\
\text { TVET } \\
\text { budget } \\
\text { of } \\
\text { MoEST }\end{array}$ & $\begin{array}{l}\text { Annual } \\
\% \\
\text { change } \\
\text { in } \\
\text { TVET } \\
\text { budget } \\
\text { of other } \\
\text { line } \\
\text { ministri } \\
\text { es }\end{array}$ & $\begin{array}{l}\text { Annual } \\
\% \text { change } \\
\text { in } \\
\text { In TVET } \\
\text { budget } \\
\text { from } \\
\text { DPS } \\
\text { annual } \\
\text { change }\end{array}$ \\
\hline $2013 / 14$ & 517240 & 80958 & 2923 & 9673 & 1513 & & & & & \\
\hline $2014 / 15$ & 594000 & 91714 & 5915 & 12604 & 1985 & 14.8 & 13.3 & 102.4 & 30.3 & 31.2 \\
\hline $2015 / 16$ & 819469 & 98643 & 5647 & 14447 & 2254 & 38 & 7.6 & -4.5 & 14.6 & 13.6 \\
\hline $2016 / 17$ & 1048921 & 116361 & 6333 & 16165 & 1927 & 28 & 18 & 12.1 & 11.9 & -14.5 \\
\hline $2017 / 18$ & 1278995 & 126642 & 6037 & 14322 & 2255 & 21.9 & 8.8 & -4.7 & -11.4 & 17 \\
\hline 2018/19 & 1315162 & 134703 & 9498 & 14322 & 3141 & 2.8 & 6.4 & 57.3 & 0 & 39.3 \\
\hline $2019 / 20$ & 1532967 & 163766 & 9899 & 14322 & 3288 & 16.6 & 21.6 & 4.2 & 0 & 4.7 \\
\hline
\end{tabular}

Journal of Education and Research, Vol. 10, No. 1, 2020 
Financing of TVET in Nepal $\mid 69$

Sources: Redbook 2013/14- 2019/20, Ministry of Finance, Annual Budget and Programme of CEHRD, CTEVT from 2013/14. Annual budget distribution of TU from 2013/14*

* The above table contains the information captured from the Annual Redbook published by the MoF. The budget allocation for fiscal year 2018/19 and 2019/20 from other ministries has not been calculated due to the resource for the local and provincial governments that have not been reflected in federal Redbook. Moreover, the budget for technical higher education has been captured from Tribhuvan University only.

The figures of Table 1 show that there has been a continued increase in national budget since 2013/14 to 2019/20. Similar case has been observed for the increment of the annual education budget. Interestingly, the annual education budget increments have appeared lower than national budget since 2014/15 to 2017/18. The TVET budget allocation from the MoEST, other line ministries and even from the development partners revealed a visible fluctuation. The average annual increment of the national budget appears at approximately $20 \%$, however, the average rate for national education budget remains only $12.6 \%$. This scenario exhibits that total education budget has not been proportionately increased at par the national budget increment. Very surprisingly, the allocation of TVET budget of the MoEST has been remained dramatically fluctuated. For example, in Fiscal Year 2014/15, its rate was increased by more than double but immediately in 2015/16, it showed a negative increment. However, in later years, the rate has been in increasing trend. Similar tendencies have been observed in the allocation of TVET budget by other line ministries and development partners. In order to explore the data in a deeper analysis, the geometric mean using factor growth rate method was also administered with the intention of identifying the rates of change of allocation of TVET budget over a period of time (see Table 2).

Table 2

TVET Budget Analysis Using Geometric Mean

\begin{tabular}{|c|c|c|c|c|}
\hline $\begin{array}{l}\text { Geometric mean } \\
\text { of national } \\
\text { budget }\end{array}$ & $\begin{array}{l}\text { Geometric } \\
\text { mean } \\
\text { education } \\
\text { budget }\end{array}$ & $\begin{array}{l}\text { Geometric mean of } \\
\text { TVET budget } \\
\text { allocated in education } \\
\text { budget (MoEST) }\end{array}$ & $\begin{array}{l}\text { Geometric mean } \\
\text { of Line } \\
\text { Ministries' } \\
\text { TVET budget }\end{array}$ & $\begin{array}{l}\text { Geometric mean } \\
\text { of DPs TVET } \\
\text { budget }\end{array}$ \\
\hline $19.9 \%$ & $12.5 \%$ & $22.5 \%$ & $6.8 \%$ & $13.8 \%$ \\
\hline
\end{tabular}

The results of Table 2 indicate that the annual growth rates of the national budget appeared at $19.9 \%$. However, the annual increment of the education budget remained at $12.5 \%$. On the other hand, the annual growth rate of TVET budget allocated in the 
70 |B. P. Aryal

education budget $(22.5 \%)$ was found at the level of national growth. Very interestingly, the annual growth rate of the line ministries' allocation on TVET was found extremely low compared to others, which was observed at the rate of $6.8 \%$. Looking at the DPs contribution on TVET, the annual growth rate $(13.8 \%)$ was also not found significant while analysing the geometric mean of the variable.

An implication can be drawn from the evidence shown in both Table 1 and Table 2 that the allocation of TVET budget was found inadequate in terms of meeting the increased demand and quality of TVET to all youths since the National Education Policy 2019 envision 'Technical education for all' with the aim of preparing capable, efficient, competitive and productive human resource for the economic development of the country.

\section{Major Findings}

The main purpose of this research was to identify the trends of TVET financing in Nepal. To analyse the trend, the researcher collected the last seven years' data starting from fiscal year 2013/14 to 2019/20. While comparing the annual data, the researcher found the average annual increment of the national budget appears at approximately $20 \%$; however, the average rate for the national education budget remains only $12.6 \%$. This scenario exhibits that total education budget has not been proportionately increased at par the national budget increment. Very surprisingly, the allocation of TVET budget of the MoEST has been remained dramatically fluctuated. For example, in Fiscal Year 2014/15, its rate was increased by more than double, but immediately in 2015/16, it showed a negative increment. However, in later years, the rate has been in increasing trend. Similar tendencies have been observed in the allocation of TVET budget by other line ministries and development partners.

Then Pearson's correlation was calculated by using SPSS software to explore the relationship relationships between and/or among total national budget and its share in TVET, total TVET budget and its share in TVET and final total government budget in TVET and support from DPs. The results demonstrate a positive association between these variables. The details are depicted in Table 3. 
Financing of TVET in Nepal |71

Table 3

Pearson Correlation of TVET budget with the Government Budget and Budget from DPs

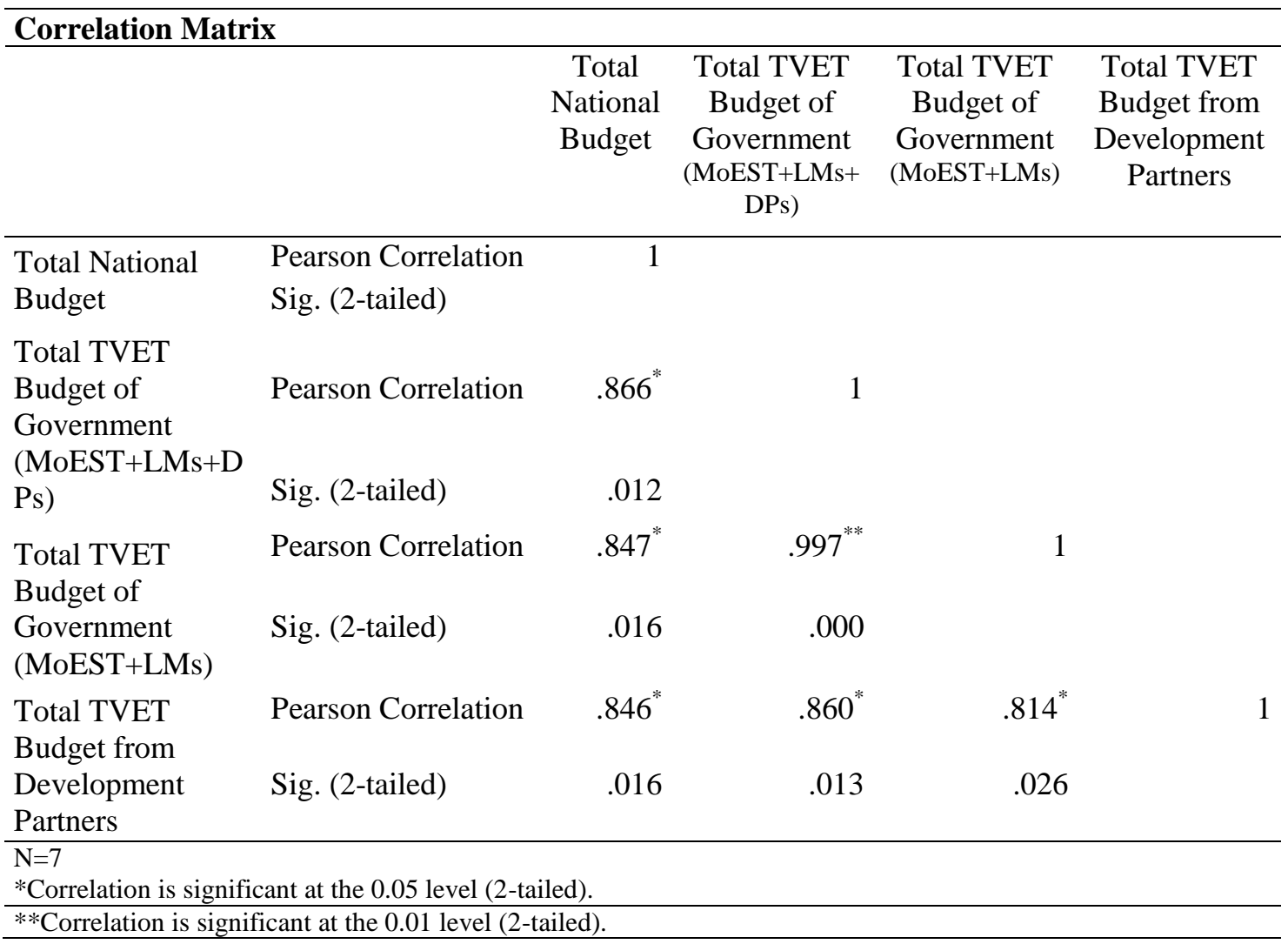

Table 3 shows the association between and/or among Government's budget and its share to TVET. The results of the computed Pearson's correlation coefficient exhibited that there were positive associations between the national budget and total TVET budget, total TVET budget and government allocation on TVET and total TVET budget and DPs' share in TVET $(\mathrm{r}=.866, \mathrm{p}=0.012<0.05 ; \mathrm{r}=.897, \mathrm{p}=0.006<0.01 \& \mathrm{r}=.814$, $\mathrm{p}=0.026<0.05)$.

\section{Policy Options to Strengthen TVET Financing in Nepal}

Regarding the alternative options to increase TVET financing in the federal system of Nepal, I tried to capture the opinion through the interviews, focused group 
discussions with the TVET experts, policymakers and TVET stakeholders to identify the appropriate fund flow mechanisms and governance systems of TVET. The key informants raised some pertinent issues on TVET governance. These issues were: access and equity in TVET opportunity, including improving quality relevance, effectiveness and efficiency of training systems, resource generation and its efficient use for TVET with sustainability.

\section{Intergovernmental Coordination and Cooperation for Good Governance in TVET}

The roles and responsibilities of each level of government for the development of the TVET sub-sector have been appeared to be clearly demarcated through integrated TVET Act. Without the legal provision, there might be some lacking and duplication in TVET programmes. A policy coordination mechanism needs to be established which can play a crucial role in enhancing coordination between all three levels of government (federal, state and local) for policy formulation and its implementation whereas the local government are to be made responsible for identifying workforce required by the local job-market based on the nature of the work and delivery of shortterm vocational training. State governments need to be made responsible for the delivery of long-term technical-vocational education and focus on compliance monitoring and evaluation of TVET programmes. At the top of it all, the federal government should be made responsible for developing TVET policy framework, institutional arrangements and coming up with quality assurance indicators to standardise delivery of TVET programmes.

\section{Youth Attraction and Mobilisation}

It is an urgent need to strengthen the traditional and indigenous occupation by rebranding and mobilise the youth to engage in economic activities through these occupations. The government can facilitate to promote these skills and occupations. We should apply the strategies to motivate youth in skill development and entrepreneurship for raising the living standard by making technical-vocational education and training more practical and responsive to the demands of the job market. Due social recognition and respect to the skilled workers would be another strategy to attract the youth in skill development. But the policy in Nepal still does not have a mechanism for lateral entry of those who are in technical vocational education and want to pursue general education and vice-versa. Therefore, to motivate youths to take up TVET, the status of technical- 
Financing of TVET in Nepal $\mid 73$

vocation education needs to be raised at par with mainstream education by ensuring permeability between the general and technical vocational education.

\section{Resource Generation and Distribution with Its Sustainability}

Establishment of TVET Fund would be the most effective way for ensuring sustainable financing for technical and vocational education and training in Nepal. This would also prove to be a more predictable source to fund training programmes while working to enhance quality, accessibility and relevancy of TVET as per the government's policy and also make it more efficient and responsive to the present-day demands of the local job market. The TVET Fund thus created would pool together resources from government budget, non-government/private sector, public and private donations, student fees as well as assistance from donors and allocate the same through a one-door system for both promotion and development of the sub-sector. Such a mechanism would also ease the procedure for investment in the TVET sector as it would do away with the unnecessary red-tape and further encourage industries and companies to come on board for the development of the sector to which they rely so much on a skilled workforce.

CTEVT, the apex body for promotion and development of TVET in Nepal, and its constituent TVET providers in the state and local level have been mobilising the resources for the promotion and development of TVET subsector and ensure aforementioned policy objective. Similarly, private TVET providers mostly raise funds to deliver TVET through student fees, but also receive government support in the form of subsidies and sharing of best practices. Therefore, the possible ways to increase investment in TVET sub-sector is funding and tax subsidies to open up industry-based training institution, provide on-the-job training and apprenticeship, levies in their production and service units and encourage the financial institutions like banks to provide educational loans to students to fund their study and training.

\section{Enhance Private Sector Engagement in TVET}

Some of the possible measures that can be used to increase and enhance private sector investment in technical and vocational education and training would be through (i) representation of private sector in the policy level committee, (ii) tax subsidies and tax exemption for private sector investing in TVET, (iii) exemption of customs duty to import educational equipment including vehicles used for transporting students and 


\section{4 |B. P. Aryal}

teaching staff, (iv) involving the private sector in long-term TVET planning and policymaking (v) providing public lands on long-term lease basis to establish training centres. To attract private sector funding in TVET, the private sector should be directly involved in sourcing and determining the allocation of funds raised from private sector contributions as well as its active involvement in governance. TVET and labour market information systems need to be strong enough so that policymakers and stakeholders can understand where the training market is not working well, where there are private under-investment or public over-investments and why such is the case. Besides, such systems need to be accessible, informative and easy to use also for students and parents to spur demands and acceptance of vocational training.

\section{Funding Framework for TVET}

Considering the current scenario of demand and supply of skilled workforce in the country, there are huge challenges in making available adequate financial resources to materialise the TVET vision in Nepal. Thus, at least two sets of policy issues need to be addressed in this regard: first, exploring and finding ways to ensure adequate funding across all TVET institutions and, second, examining the role of government and other TVET stakeholders and beneficiaries in addressing these challenges. Credible costbenefit analyses, as well as realistic cost projections for resource generation and funding of recurrent expenditures, could be done so that the private sector can also feel assured of their investment. Performance-based budgeting schemes could be effective if quality in TVET is defined, and outcomes are measured to assist institutions to improve quality. Similarly, subsidies, loans, funds and training voucher systems can be a highly effective means for financing and revising demand orientation of TVET. Generating more in-country employment through a robust job market would significantly reduce the contribution of remittance to the country's GDP, which currently stands at $25 \%$ (MoF, 2019). Self-employment and entrepreneurship-oriented training would be very effective in this regard.

Although the contribution of remittance to Nepal's economy cannot be entirely reduced, the new and innovative skills acquired by returnee migrants would be very useful for the local economy and the market. It would not only help in skill transfer but also encourage the transfer of modern technology that will ultimately benefit the country's industries and businesses. Therefore, the government can also provide priority 
loans and subsidies to the returnee migrant to become entrepreneurs and implement the skills and expertise they have learnt abroad to generate employment and contribute to economic growth.

\section{Reflections on Financing TVET}

Though the trend of budget allocation for TVET sector is highly correlated to the total national budget and total education budget, the actual allocation still seems to be significantly low especially given that the government has identified TVET as key to jump-starting nation-wide reform agenda for the overall development of the nation. Similarly, to achieve the targets set in SDG4 to ensure quality technical and vocational education for all women and men, and substantially increase the number of youth and adults with relevant skill including technical and vocational skills for employment, decent work and entrepreneurship by 2030 (UNESCO, 2016) the financial arrangement made by the government of about $7 \%$ of the national education budget is not sufficient. Therefore, the government allocation in the TVET sector should be increased to fulfil the minimum requirement for ensuring quality TVET and expanding it in order to make it accessible for all. The internal resource of the developing countries could not address the reform agenda in education, including TVET, so the need to mobilise the support from the international community (multilateral organisations, financial institutions, investors and philanthropic institutions), i.e. should increase external financing as recommended by the education commission report 2016.

To bring about immediate and immense reforms in TVET sector of Nepal, increasing focus should be directed towards the improvement of major four areas, (a) strengthen legal foundation (b) intergovernmental coordination for TVET governance (c) resource harmonisation with appropriate fund flow mechanism and (d) effective private sector engagement in TVET as per the recommendations made by Renold et al. (2018). They also emphasise on creating an Inter-Governmental TVET Coordination Committee to act as a high-level steering committee, redefining a TVET policy for 2030 linking with SDGs, developing an integrated TVET Act, and developing an evidence-based financial flow mechanism on TVET. Among the aforementioned recommendations, the effective and transparent financial flow appears to be an extremely important prerequisite for efficient TVET system in the federal context of Nepal. 
Nepal has now entered into the federal governance system. The national government itself cannot single-handedly address the financial requirement to bring about reform in TVET sub-sector. Therefore, shared responsibility of all levels of government in ensuring continued financing in TVET will be instrumental for resource generation and mobilisation in TVET. In regards to financial sustainability, different models can be used in TVET financing in Nepal. These models could be:(i) establishing TVET fund based on sector-wide approach for the resource generation and mobilisation of the development partners' support in TVET sector; (ii) voucher system, (iii)institutionbased allocation, (iv)apprenticeship, (v) partnership with the private sector, (vi) corporate social responsibility for resource allocation to strengthen TVET. Furthermore, providing priority loans and subsidies to the economically poor people and the returnee migrants for skill development and entrepreneurship purposes could also be applied. Funds with a diverse source of finance (i.e. earmarked payroll levies, government sources, external sources, etc.) can also be established and utilised in the context of Nepal as Lauglo, (2006) said in relation with the industrial sector to supply required human resource for them. Earmarked training levies have emerged as the most widely adopted alternative measure identified by the central government for budgetary allocation for TVET (Ziderman, 2016) and introduced in some countries such as Brazil, Latin America, and the Caribbean, Tanzania and Fiji. The same strategy can be appropriate in the case of Nepal as well.

The finding of this study reveals that TVET financing has been influenced mainly by the national economy, equity and inclusion, intergovernmental coordination, global political context, external funding, private sector engagement, and mobilisation of the youth. The evidence shows that these factors contribute to shaping the financing of TVET, equity-based distribution of the resources, and strengthen efficiency and effectiveness among the levels of the governments following the fiscal equalisation theory and second-generation theory (Dung, 2015; Ejobaha, 2018; Thomson, 2000).

\section{Recapitulation and Conclusion}

This study comes up with a conclusion that the establishment of a TVET fund would be an effective model to pool and mobilise resources in order to strengthen the voucher system and apprenticeship model with the partnership of private sector. In addition, soft loans and institutional-based subsidised funding mechanism have been identified as key 
Financing of TVET in Nepal $\mid 77$

instruments to attract the youth and the returnee migrants for the development of skills and entrepreneurship. There are some possible ways to increase investment in TVET sub-sector in Nepal through tax subsidisation to private sectors to open up industrybased training institutions, strengthen the apprenticeship model. In addition, levies to employees and developing a mechanism of encouraging financial institutions like banks, cooperatives would be viable instruments to reach the unreached in TVET. Since the cost of TVET appeared relatively higher than the general education, one of the critical findings captured in this paper, thus, highlighted an urgent need of establishing a common understanding, coordination, collaboration and cooperation mechanism between three levels of government to ensure adequate financing in TVET. For this, an Inter-Governmental TVET Coordination Committee needs to be established to act as a high-level steering committee for linking TVET with SDGs. The evidence of this research has further encouraged to claim some prospects of the possibility of integrating or pooling of funds from governmental, non-governmental and from private sectors to largely benefit the youth population through employment generation programmes and bring about the economic development of the country.

\section{References}

Asian Development Bank. (2009). Financing technical and vocational education and training in the People's Republic of China.

http://hdl.handle.net/11540/203

Asian Development Bank. (2015). Innovative strategies in technical and vocational education and training for accelerated human resource development in South Asia: Nepal. https://www.adb.org/sites/default/files/publication/176564/tvet-hrd-southasia-nepal.pdf

Alam, N. (2015). The role of technical vocational education and training in human development: Pakistan as a reference point. European Scientific Journal, 11(10), 3550. http://eujournal.org/index.php/esj/article/view/5407

Becker, G.S. (1994). Human capital: A theoretical and empirical analysis with special reference to education (3rd ed.). The University of Chicago Press.

Best, J. W., \& Kahn, J. V. (2002). Research in education (7th ed.). Prentice Hall. Braga, M., Checchi, D., \& Meschi, E. (2013). Educational policies in a long-run perspective. Economic Policy, 28(73), 45-100. 
78 |B. P. Aryal

Center for Research and Development Services. (2018). TVET financing in Nepal: Final report.

Central Bureau of Statistics. (2019). Report on the Nepal labour force survey 2017/18.

Chen, Y. (2017). Graduate employability: The perspective of social network learning. Journal of Mathematics, Science and Technology Education, 13(6), 2567-2580.

Dubin, R. (1978). The theory building. The Free Press.

Dung, P.Q. (2015). Fiscal equalisation from theory to practice: A comparative study on Australia, Germany and Switzerland [Master's thesis, University of Tampere]. https://trepo.tuni.fi/handle/10024/98990

Ejoboha, J. B. (2018). The second-generation theory of fiscal federalism: A critical evaluation. Perspectives on Federalism, 10(1), 220-242. https://doi.org/10.2478/pof2018-0011

Fuller, A., \& Unwin, L. (2013). Gender segregation, apprenticeship, and the raising of the participation age in England: Are young women at a disadvantage? Centre for Learning and Life Chances in Knowledge Economies and Societies. http://hdl.voced.edu.au/10707/284004

General Directorate for Vocational Training. (2007). A report of financing of technical and vocational education and training (TVET), Vietnam. Vietnamese-German Development Cooperation.

Grindle, M. S., \& Thomas, J. W. (1991). Public policy and policy change: The political economy of reform in developing countries. Johns Hopkins University Press.

Hasan, K. Z. B., \& Mokhtar, M. B. (2013). Human capital and educational finance: A review of literature. International Journal of Science Commerce and Humanities, l(1), 1-7.

Hatlebakk, M. (2017). Nepal: A political economy analysis. Norwegian Ministry of Foreign Affairs.

International Centre for Technical and Vocational Education and Training of the United Nations Educational, Scientific and Cultural Organization. (1996). Financing technical and vocational education: Modalities and experiences.

International Commission on Financing Global Education Opportunity. (2016). The learning generation: Investing in education for a changing world.

Johansen, R. (2009). A review of national training funds. The World Bank. 
Financing of TVET in Nepal $\mid 79$

Karmel, T. (2015). Notional data standard for a TVET finance data collection:

Overview paper. Australian Council for Educational Research.

https://bit.ly/34sxDBE

Kennedy, D. (2013). Law and the political economy of the world. Leiden Journal of International Law, 26, 7-48.

Kingdon, G. G., Little, A., Aslam, M., Rawal, S., Moe, T., Patrinos, H., Beteille, T., Banerji, R., Parton, B., \& Sharma, S. K. (2014). A rigorous review of the political economy of education systems in developing countries: Final report. Department for International Development.

Lauglo, J. (2006). Research for TVET policy development. UNEVOC.

Ministry of Education, Science and Technology. (2019). A report of high-level national education commission, 2018.

Ministry of Education. (2012). Technical and vocational education and training (TVET) policy.

Ministry of Education/Bangladesh. (2011). National skills development policy, 2011.

Ministry of Federal Education and Professional Training/Pakistan. (2015). Skills for growth and development: A technical and vocational education and training (TVET) policy for Pakistan.

Ministry of Finance. (2019). Economic survey, 2018/19.

Ministry of Law, Justice and Parliamentary Affairs. (2015). The constitution of Nepal.

Mosco, V. (2009). The political economy of communication (2nd ed.). Sage.

National Planning Commission. (2019). 15th plan: Approach paper.

Parajuli, M. N., \& Shakya, R. M. (2012). Resource needs assessment for technical and vocational education and training (TVET) sub-sector in Nepal. Ministry of Education.

Parajuli, M. N. (2013). Rhetoric of developing technical and vocational education and training (TVET) in Nepal: Analysis of the financing of the sub-sector. Technical and Vocational Education and Training Development Journal, 13(1), 58-68.

Renold, U., Bolli, T., \& Caves, K. (2018). Constitutional reform and its impact in TVET of Nepal. KOF-Swiss Economic Institute, ETH Zürich.

Renold, U., \& Caves, K. (2017). Constitutional Reform and its impact on TVET governance in Nepal: A report in support of developing understanding and finding the way forward for federalising the TVET sector in Nepal. KOF Swiss Economic Institute. 
$80 \mid$ B. P. Aryal

Thompson, W. R. (2000). The emergence of the global political economy. Tailor \& Francis.

United Nations Educational, Scientific and Cultural Organization. (2003). Financing of education: South and east Asia regional report.

United Nations Educational, Scientific and Cultural Organization. (2013). Policy review of TVET in Cambodia.

United Nations Educational, Scientific and Cultural Organization. (2016). Incheon declaration and framework for action for the implementation of Sustainable Development Goal 4.

Vollmann, W. (2010). The challenge of technical and vocational training and education in rural areas: The case of South-Asia. Journal of Education and Research, 2,5258. https://doi.org/10.3126/jer.v2i0.7623

Wang, G. C. (Ed.). (1977). Fundamentals of political economy. M. E. Sharpe.

Ziderman, A. (2016). Funding mechanisms for financing vocational training: An analytical framework (IZA Policy Paper No. 110). http://ftp.iza.org/pp110.pdf

\section{To cite this article:}

Aryal, B. P. (2020). Financing of technical and vocational education and training in Nepal. Journal of Education and Research, 10(1), 58-80. https://doi.org/10.3126/jer.v10i1.31898 